\title{
THE EFFECT OF PROBLEM BASED LEARNING MODEL AND MATHEMATIC-LOGICAL INTELLIGENCE TOWARD MATHEMATICS LEARNING ACHIEVEMENT
}

\author{
Melkior Wewe \\ STKIP Citra Bakti, Nusa Tenggara Timur, Indonesia \\ Email: melkiorwewe1@gmail.com
}

\begin{abstract}
This study aims to find out the difference between the model of problem-based learning and the mathematical-logical intelligence towards mathematics learning achievement. This study is a true experimental with specific design of post-test only control group design. The population of this study are all fourth grade students of primary schools in Bajawa sub district. Meanwhile, the sample in this study is determined through random sampling. The result of analysis, it is gained that the learning achievement which used problem based learning model is higher than the mathematics learning achievement of the students with the conventional learning technique. The calculation from two ways ANAVA results in Fobs 1.793 with sig = 0.184 , there is no significant effect of learning interaction model and mathematic-logical intelligence. Since there is no interaction, it also means that there is no significant effect of problem based learning collaborated with mathematic-logical intelligence to the students' learning achievement.
\end{abstract}

Keywords: logical intelligence, learning achievement, PBL

\section{Introduction}

Indonesian government policy about national education system (Undang-Undang Nomor 20 Tahun 2003 pasal 1 ayat 1 ) states that education is a conscious and planned effort to create a suitable learning atmosphere and learning process as well as making learners to develop their potential in various aspects such as spirituality, selfcontrol, personality, intelligence, morality, and skills for themselves, society, and the nation. Pursuing such target needs a proper and suffice human resources who have high intelligence and being able to process every information that comes to them. One of the ways to achieve it is through education. The process of education needs to be run well to prepare them facing the real challenge in society. In Indonesian present curriculum (Kurikulum 2013), a learning process is conducted interactively, inspirational, comfortably, challenging, and motivating to make learners actively participate in class. It is also useful to lead them to be creative, independence, and making them be able develop their potential physically and psychologically.

Hudojo (2003:78) argues that learning mathematics, from the constructivism point of view, is a process of building concepts or principles with their own ability through internalisation process. Constructivism sees a knowledge as a construction derived from someone's activity. Based on its beliefs, knowledge is not a fact to be learnt but a constructive cognitive built from experience. Knowledge is also defined as consecutive construction of somebody and can be re-organised due to new experience. This principle has been continuously applied in the area of mathematics learning.

Problem based learning roots from Jhon Dewey's definition who state a school should be a reflection of a bigger community and classroom is a laboratory to solve real life problems. Problem based learning is a strategy which is based on constructivism approach and it accommodates learners in solving authentic problems. In gathering the information and developing it into topics, learners learn how to construct a preconceived ideas, organising and investigating problems, gathering and analysing data, ordering facts, and constructing a concept to solve their problems, working either individually or collaboratively in solving the problems (Marhaeni, 2013:137). According to Sanjaya (2010:214), problem based learning is a set of activities which emphasizes on scientific problem solving. The syntax of problem based learning is divided into 6 phases as the following, 1) formulating problems, it is the phase or stage where problems are encountered and stated to be the one that need to be solved, 2) analysing problems, it is when learners consider the problems from different angle, 3) formulating a hypothesis and the ways to solve it, 4) gathering data, it is the process where the learners search and forming the solution to their problems, 5) hypothesis testing, it is a process where learners wrench out the conclusion based on the fact they gather, 6) stating a recommendation based on their experience in solving the problems.

Intelligence is also related to creativity, personality, mind set, knowledge, and wisdom. However, some psychologists do not include the aforementioned terms to their definition of intelligence. It usually refers to the ability or mental capacity in thinking, yet still there is no satisfying definition to intelligence. Generally, the left 
hemisphere of human brain plays a key role to processing a logic, words, mathematics, orders, and also numbers which then being called academic learning. On the other hand, the right hemisphere deals with rhythm , music, pictures, and imagination which then being called as creative activity.

According to Lwin et al. (2008:43), mathematic-logical intelligence is an ability to deal with numbers and calculation, pattern, logical and scientific thoughts. In addition, Piaget in Campbell et al. (2005:40), mathematic-logical intelligence starts from an interaction between a child and objects around him, acknowledging numbers, shift from concrete objects to abstract symbols, manipulating abstract symbols and considering statements hypothetically and relate it to its implication.

From the aforementioned arguments by experts, mathematic-logical intelligence is defined as someone's ability to implicate components such as mathematical calculation and measurement, logical thinking, problemsolving, deductive and inductive approach, and accuracy of pattern and its relation as well the implications. According to Cronbach as cited in Suryabrata (2002:231), the best way to learn is by experiencing, and by that a learner will utilise his five senses. Furthermore, Gagne in Mudjiono (2002:8) states that learning is a set of cognitive process that can stimulate characteristics, undergo an information processing to be a new capacity. Slameto (2003) also argues that learning is a set of effort done by somebody to achieve a change of holistic characteristics, as a result from his/her experience in interacting with their surroundings.

Taking into account of the aforementioned explanation, the hypothesis of this present study is formulated as follows. 1) there is a significant difference in students learning achievement in mathematic subject between those who are treated by using problem based learning compared to those who are treated by using conventional technique, 2) there is a significant difference in students learning achievement between those who have higher mathematic-logical intelligence compared to those who are lower, 3) there is a significant effect of the interaction in problem based learning and mathematic-logical intelligence toward the students' learning achievement. The objective of this study can be formulated as follows. 1) to investigate the difference in students' learning achievement between those who are treated by problem based learning and those who are treated by conventional teaching technique, 2) to find out whether or not there is significant difference between those who have higher mathematic-logical intelligence compared to those who have lower mathematic-logical intelligence, 3) to find out the effect of interaction between problem based learning and mathematic-logical intelligence toward students' learning achievement in mathematic subject.

\section{Method}

This present study aims to find out the effect of problem based learning and mathematic-logical intelligence toward students learning achievement by manipulating the independent variable which is problem based learning and mathematic-logical intelligence and the dependent variable which is the students' learning achievement. Meanwhile the other variable aside from those have been mentioned earlier are hardly controlled. This study is true experimental research (Sugiyono, 2008:114) with posttest only control group design is chosen to be the design of the study. The detail of the design can be seen on table 1 .

Population is a generalisation area consisted of objects/subjects that has certain quality and characteristics to be investigated and concluded by researchers (Sugiyono, 2008:117).

Table 1. Research Design

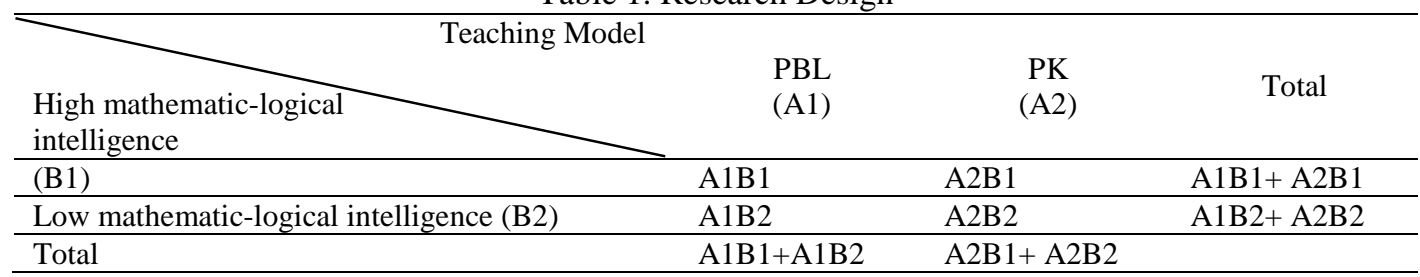

Note:

$\begin{array}{ll}\text { PBL(A1) } & \text { : Problem Based Learning } \\ \text { PK(A2) } & \text { : Conventional Technique } \\ \text { A1B1 } & \text { : PBL group with higher logical intelligence } \\ \text { A1B2 } & \text { : PBL group with lower logical intelligence } \\ \text { A2B1 } & \text { : Conventional group with higher logical intelligence } \\ \text { A2B2 } & \text { : conventional group with lower logical intelligence }\end{array}$

The population in this study covers all elementary schools in Bajawa sub district in academic year 2015/2016. In choosing the sample, the researcher administers simple random sampling where 50 students are selected as the experimental group and 50 students for the control group. In gathering the data needed, posttest is conducted after the treatment has completed. The posttest itself is expected to give data about students' learning 
achievement in mathematic subject. Instruments are also utilised to measure students' learning achievement in both conventional group who are treated by using conventional technique and experimental group who are treated by using problem based learning. . The research procedure for the experimental group is formulated as follows: 1) investigating students' problem, 2) analysing the problem, 3) formulating hypothesis, 4) gathering data, 5) hypothesis testing, 6) constructing a solution to th problems. Meanwhile, the procedure which is applied in conventional group can be seen as follows; 1) explaining theories, 2) giving examples, exercise, and homework. The researcher uses test as the instrument of the study. Before the test is administered, the researcher has validated it through validity test and reliability test. This study will try to distinguish the score gaps between the two independent variables, therefore, the hypothesis testing will utilise two ways analysis of variance (ANOVA) with F test. This testing requires assistance from SPSS 16.0 for windows. If it is found that there is a significant effect of interaction between mathematic-logical intelligence and learning strategy, the researcher will continue to test it by T-test.

\section{Findings and Discussion}

In this phase, the test is valid if $r_{\mathrm{pb}}$ (point biserial correlation) is utilised by df (degree of freedom) in total of $(\mathrm{N}-\mathrm{nr})$ with $\mathrm{N}=$ total students number and $\mathrm{nr}=2$, and then the $\mathrm{r}_{\mathrm{pb}}$ is compared to the $\mathrm{r}_{\text {table }}$ with $5 \%$ level of significance. After conducting a validity test, the item will considered as valid if $r_{o b s}$ is higher than $r_{\text {table }}\left(r_{o b s}>\right.$ $\mathrm{r}_{\text {table }}$ ) for significance level $\alpha=5 \%$ and $\mathrm{n}=$ total sample. Based on the analysis to 20 items of questions, it is gained that there are 15 items which are valid and 5 items which are not. In determining the degree of reliability test, the researcher uses the criteria set by Guilford (Koyan, 2013). From the calculation, it is gained that r.11=0.803. After being checked to the criteria from Guilford, that score is categorised as highly reliable. Thus, the instrument can be used for the posttest. The object in this study is the different score between students who are treated by problem based learning and those who are treated by conventional technique by considering students' level of intelligence. This study applies the factorial design $2 \times 2$ by using two ways ANAVA as a mean to analyse the data.

Table 2 Tabulation Score on Central Tendency of the Students' Achievement in Mathematic Subject toward Fourth Grade Students through PBL and Conventional Technique

\begin{tabular}{|c|c|c|c|}
\hline \multirow{10}{*}{ Students' Learning Achievement } & \multicolumn{2}{|l|}{ MP } & \multirow{2}{*}{$\frac{\text { Statistic }}{11.6600}$} \\
\hline & \multirow[t]{5}{*}{ PBL } & Mean & \\
\hline & & Median & 12.0000 \\
\hline & & Variance & 2.596 \\
\hline & & Std. Deviation & 1.61131 \\
\hline & & & Statistic \\
\hline & \multirow{4}{*}{$\begin{array}{l}\text { Conventional } \\
\text { Technique }\end{array}$} & Mean & 7.3400 \\
\hline & & Median & 7.0000 \\
\hline & & Variance & 4.147 \\
\hline & & Std. Deviation & 2.03650 \\
\hline
\end{tabular}

Table 3 Recapitulation Score of High Mathematic-logical Intelligence Students and Low Mathematic-logical Intelligence Students

\begin{tabular}{|c|c|c|c|}
\hline & Mathematic-Logical Intelligence & & Statistic \\
\hline \multirow{8}{*}{$\begin{array}{l}\text { Students' } \\
\text { Learning } \\
\text { Achieveme } \\
\text { nt }\end{array}$} & \multirow[t]{4}{*}{ Higher } & Mean & 10.7000 \\
\hline & & Median & 11.0000 \\
\hline & & Variance & 3.847 \\
\hline & & Std. Deviation & 1.96136 \\
\hline & \multirow[t]{4}{*}{ Lower } & Mean & 6.6000 \\
\hline & & Median & 7.0000 \\
\hline & & Variance & 3.469 \\
\hline & & Std. Deviation & 1.86263 \\
\hline
\end{tabular}


Table 4. The Hypothesis Testing

\begin{tabular}{llllll}
\hline Source & Type III Sum of Squares & df & Mean Square & F & Sig. \\
\hline Corrected Model & $623.560^{\mathrm{a}}$ & 3 & 207.853 & 115.048 & .000 \\
\hline Intercept & 9025.000 & 1 & 9025.000 & $4.995 \mathrm{E} 3$ & .000 \\
\hline $\mathrm{A}$ & 466.560 & 1 & 466.560 & 258.244 & .000 \\
\hline $\mathrm{B}$ & 153.760 & 1 & 153.760 & 85.107 & .000 \\
\hline $\mathrm{A} * \mathrm{~B}$ & 3.240 & 1 & 3.240 & 1.793 & .184 \\
\hline Error & 173.440 & 96 & 1.807 & & \\
\hline Total & 9822.000 & 100 & & & \\
\hline Corrected Total & 797.000 & 99 & & & \\
\hline
\end{tabular}

a. R Squared $=, 782$ (Adjusted R Squared $=, 776)$

\section{Discussion}

The first formulation of the hypothesis state that there is a significant difference between students who are treated by problem based learning and those who are treated by conventional technique. This hypothesis is tested by calculating the $\mathrm{F}_{\mathrm{obs}}$ and being compared to $\mathrm{F}_{\text {tab }}$ or coefficient sig. which is compared to 0.05 . The result of calculation from two ways ANAVA in SPSS 16.0 reveals that the $F_{\text {obs }}$ with learning strategy (Column A) is 258,244, and sig. 0,00. Since sig. $0,00<0,05$, this means the null hypothesis $\left(\mathrm{H}_{0}\right)$ which is there is no significant difference between students who are treated by using problem based learning and those who are treated by conventional technique is rejected. Thus, the alternative hypothesis $\left(\mathrm{H}_{\mathrm{a}}\right)$ which states that there is a significant difference between students who are treated by using problem based learning and those who are treated by conventional technique is accepted. This shows that there is a different achievement between students who learn through problem based learning compared to conventional technique. In mathematic subject, problem based learning has proven more effective compared to the conventional one. This is caused by the condition when they are treated by problem based learning. Students are given more life-like mathematic problems in which it is also the real application of concepts they get. It leads students to be accustomed to solve problems in reality. This first hypothesis testing also proves that the concept of mathematic learning needs to shift students' concept from abstract concept to real situation or experience. For instance, geometry and two dimensional figure are basically coming from measuring concrete materials through abstracting it. In short, it is concluded that problem based learning is a technique to help students understanding a concept by giving them problems which are closely related to their daily through a challenging, active, and creative process of learning.

As for the second hypothesis in this study, there is a significant difference in students' learning achievement between students who have higher mathematic-logical intelligence and those who have lower mathematic-logical intelligence. This hypothesis is tested by comparing the $\mathrm{F}_{\text {obs }}$ and the $\mathrm{F}_{\text {table }}$ or the calculation on coefficient sig. with 5\% significance level. The result of calculation from two ways ANAVA shows that the $\mathrm{F}_{\mathrm{obs}}$ is 85.107 with sig value 0,00 . Since sig. $0,000<0,05$, this means the null hypothesis $\left(\mathrm{H}_{0}\right)$ is rejected, yet the alternative hypothesis $\left(\mathrm{H}_{\mathrm{a}}\right)$ is accepted. Therefore, it is concluded students who have higher mathematic-logical intelligence get better score compared to those who have lower mathematic-logical intelligence. According to Lwin et al. (2008:43), mathematic-logical intelligence is someone's ability to handle numbers, calculation, pattern, logical thinking, and scientific. Students with higher mathematic-logical intelligence are good at quick calculation, skilful in solving problems, inductive and deductive reasoning, and logical thinking in taking conclusion. It is necessary to have it since mathematic learning requires active participation to construct new knowledge. In its application, high intelligence students who are taught by problem based learning tends to be more active in learning, having quick response to answer questions, and needing shorter time to conclude things compared to the lower one. Low mathematic-logical intelligence students often feel oppressed when they learn through problem based learning. Students are required to be able to solve problems using their comprehension of mathematic concept more quickly. This is due to their needs to apply this in real life. In this respect, teacher's role is being a facilitator for their students, guiding, and observing them. This causes students with lower mathematical intelligence struggling to follow the lesson and affect their achievement. However, they are good at following the procedure in conventional technique, they are comfortable with teacher's explanation, doing exercise together, and good discussion. Once they are comfortable with it, they are also motivated to learn intensively. From those explanations, it is concluded that mathematic-logical intelligence is an inner factor to help students to interact with mathematical areas.

The third hypothesis in this study is that there is a significant effect of interaction between mathematiclogical intelligence and problem based learning toward students' learning achievement. The test looks at the sig value, when it is $0,00<0,05$, that means there is significant effect of interaction between mathematic-logical intelligence and problem based learning toward students' learning achievement. On the contrary, when sig.> 0,05, 
it is concluded that there is no significant effect of mathematic-logical intelligence and problem based learning toward students' learning achievement. From the calculation, it is gained that the $F_{\text {obs }}$ is 1.793 with sig. $=0.184$. Since sig. $0.184>0.05$, the null hypothesis is accepted and alternative hypothesis is rejected. In other words, there is no significant effect of problem based learning and mathematic-logical intelligence.

This study reveals that students' learning achievement in mathematic subject relies much on the students' mathematic-logical intelligence or problem based learning as the method, but no interaction found between them to have a significant effect toward students' achievement. The absence of the interaction is mostly caused by the lower mathematic-logical intelligence students who tend to follow conventional technique more easily rather than problem based learning.

\section{Conclusion}

From the analysis and discussion from the previous part of this article, the researcher can conclude this study as the following: 1) the two ways ANAVA test reveals that there is a significant difference in students' learning achievement between students who are taught by using problem based learning compared to those who are taught by conventional technique. It is reflected by the score obtained in $\mathrm{F}_{\text {obs }}$ with 258.244 and sig. 0,00. 2) The analysis shows that the $\mathrm{F}_{\mathrm{obs}}$ of the factor in the learning strategy is 85.107 with sig. 0,00 . This means students who have higher mathematic-logical intelligence get better score than the lower mathematic-logical intelligence. 3 ) The result of ANAVA test reveals that the $F_{\text {obs }}$ is 1.793 with sig= $0.184(0.184>0.05)$, thus $\mathrm{H}_{0}$ is rejected and $\mathrm{H}_{\mathrm{a}}$ is accepted. Furthermore, this also means that there is no interaction between the learning strategy (problem based learning) and mathematic-logical intelligence.

\section{References}

Campbell, et al. (2005). Metode Praktis Pembelajaran Berbasis Multiple Intelligences. Depok : Intuisi Press. Hudoyo, H. (2003). Metode Mengajar Matematika. Malang: IKIP Malang.

Koyan, I W. (2013). Assemen Pendidikan. Universitas Pendidikan Ganesha. Press.

Lwin, M. et al. (2008). How To Multiply Your Child's Intelligence, Cara Mengembangkan Berbagai Komponen Kecerdasan. Jakarta : PT. Indeks.

Marhaeni, A. A. (2013). Strategi Belajar Mengajar. Universita Pendidikan Ganesha. Press.

Dimyati \& Mudjiono. (2002). Belajar dan Pembelajaran. Jakarta: Rineka Cipta

Sanjaya, W. (2010). Strategi Pembelajaran Berorientas KTSP. Jakarta: Prana Media

Slameto. (2003). Belajar dan Fakto-faktor yang Mempengaruhinya. Jakarta. PT. Rineka Cipta.

Soedjadi, R. (2001). Pemanfaatan Realitas dan Lingkungan dalam Pembelajaran Matematika. Paper presented on National Seminar in FMIPA UNESA, Pebruary 24, 2001.

Sugiyono. (2008). Metode Penelitian Pendidikan (Pendekatan Kuantitatif, Kualitatif dan Metode R\&D) $6^{\text {th }}$ printed. Bandung : Alfabeta.

Suryabrata, S. (2002). Psikologi Pendidikan. Jakarta : PT. Raja Grafindo Persada. 